Potpukovnik dr MILJAN MILKIĆ, naučni saradnik

Institut za strategijska istraživanja

Beograd, Neznanog junaka 38

miljan.milkic@mod.gov.rs

UDK 327(497.1:450)"1946/1951"

339.92(497.1:450)"1946/1951"

originalan naučni rad

primljeno: 12. septembar 2015.

prihvaćeno: 4. novembar 2015.

\title{
OBNOVA TRGOVINSKIH VEZA JUGOSLAVIJE I ITALIJE POSLE DRUGOG SVETSKOG RATA*
}

APSTRAKT: $U$ članku se analizira proces obnove trgovinskih odnosa Jugoslavije i Italije posle Drugog svetskog rata. Autor ukazuje na političke probleme koji su uticali na potpisivanje trgovinskog sporazuma. Članak je pisan na osnovu dokumenata iz Diplomatskog arhiva Ministarstva spoljnih poslova Republike Srbije, Arhiva Jugoslavije, objavljene arhivske grade i literature.

KLJUČNE REČI: Jugoslavija, Italija, Mirovni ugovor, jugoslovenski Trgovinski biro u Milanu, trgovinski sporazum, politički odnosi, Maršalov plan

Obnovu diplomatskih odnosa sa Italijom posle Drugog svetskog rata jugoslovenska vlada je uslovljavala potpisivanjem mirovnog ugovora i rešavanjem pitanja teritorijalnog razgraničenja koja su još od kraja Prvog svetskog rata opterećivala međusobne odnose. ${ }^{1}$ Do uspostavljanja diplomatskih odnosa, Jugoslavija je svoje političke i ekonomske interese u Italiji štitila preko Jugoslovenske delegacije u Savetodavnom veću za Italiju. ${ }^{2}$ Mirovni ugovor potpisan 10. februara 1947. u Parizu nije doneo očekivano rešenje spornih pitanja, ali je predstavljao osnovu za obnovu političkih, ekonomskih i kulturnih odnosa dveju zemalja. Proces uspostavljanja diplomatskih odnosa počeo je januara 1947. kada je jugoslovenska vlada obavestila italijansku vladu o svojoj nameri da uspostavi političko predstavništvo. ${ }^{3}$

* Rad je deo projekta Srbi i Srbija u jugoslovenskom i međunarodnom kontekstu: unutrašnji razvitak i položaj u evropskoj/svetskoj zajednici (47027) koji finansira Ministarstvo prosvete, nauke i tehnološkog razvoja Republike Srbije.

${ }^{1}$ Миљан Милкић, „Југославија, велике силе и питање статуса Јулијске крајине 1943-1945", у: Ослобођење Беоіраga 1944. іолине, Зборник радова, уредник Александар Животић, (Београд: ИНИС, 2010), 282-296.

2 Миљан Милкић, „Гашење југословенске краљевске војне мисије у Италији 1945“, Војноисиооријски іласник, бр. 2, (2010), 149.

${ }^{3}$ Diplomatski arhiv Ministarstva spoljnih poslova (DA MSP), Politička arhiva (PA), 1947, f. 48 , br. 41030 . 
Jugoslovenski poslanik u Rimu Mladen Iveković predao je akreditivna pisma 29. jula 1947. ${ }^{4}$ Italijanski poslanik Enriko Martino (Enrico Martino) stigao je u Beograd sredinom jula 1947. ${ }^{5}$ Tokom narednih godina, implementacija Ugovora o miru i rešavanje pitanja ratnih zarobljenika, ratnih zločinaca, reparacija, restitucija, bila su najosetljivija pitanja. Najveći problem predstavljala su pitanja teritorijalnog razgraničenja na prostoru Julijske krajine i teritorijalnog statusa grada Trsta. Bilateralni odnosi bili su opterećeni čestim pograničnim incidentima na kopnu i moru. Prema podacima Savezničke kancelarije za civilne poslove i vezu (koja je preuzela funkcije bivše Savezničke komisije), jugoslovenske vlasti su od 1. aprila 1945. do 3. februara 1947. u jugoslovenskim teritorijalnim vodama zaplenile 37 italijanskih brodova pod optužbom da se bave nedozvoljenom trgovinom. ${ }^{6}$

Osnova za kreiranje i realizaciju jugoslovenske ekonomske politike prema Italiji bila je sadržana u članu 82 Ugovora o miru sa Italijom kojim su definisane smernice za uspostavljanje ekonomskih odnosa između Italije i država članica Ujedinjenih nacija. ${ }^{7}$ Tokom 18 meseci posle stupanja na snagu Ugovora o miru sve države Ujedinjenih nacija uživale su klauzulu najvećeg povlašćenja u pogledu svega što se odnosi na dažbine i terete na uvoz i izvoz na oporezivanje $u$ zemlji uvezene robe i na sve uredbe u vezi s tim. Italija nije smela da proizvoljno čini diskriminaciju na štetu robe koja potiče sa teritorije članice Ujedinjenih nacija ili koja se upućuje na tu teritoriju, u odnosu na sličnu robu koja potiče sa teritorije neke druge članice Ujedinjenih nacija ili bilo koje druge strane zemlje, ili se upućuje na tu teritoriju.

\section{Jugoslovenski Trgovinski biro u Milanu}

Jugoslovenska vlada je nastojala da pre uspostavljanja diplomatskih odnosa sa Italijom preko Ekonomskog odeljenja Jugoslovenske delegacije u Savetodavnom veću obezbedi funkcionisanje trgovinskog prometa. Kao jedan od načina za uspostavljanje trgovine, jugoslovenska vlada je predložila otvaranje Trgovinskog biroa u Milanu, za čije je funkcionisanje italijanska vlada u oktobru 1946. dala načelni pristanak. ${ }^{8}$ Jugoslovenski Trgovinski biro je i bez formalne dozvole italijanske vlade počeo da deluje u Milanu sredinom decembra 1946. i trgovinska razmena sa Italijom je počela da se obavlja. ${ }^{9}$ Italijanska vlada je 20 . decembra upozorila da neće dozvoliti rad

${ }^{4}$ DA MSP, PA, 1947, f. 49, br. 414316.

${ }^{5}$ DA MSP, PA, 1947, f. 50, br. 414283.

${ }^{6}$ DA MSP, PA, 1947, f. 55, br. 45069.

7 „Указ о ратификацији Уговора о миру са Италијом“, Службени лисй ФНРЈ, 29.

8. 1947, 1001-1085.

${ }^{8}$ DA MSP, PA, 1947, f. 50, br. 15195.

${ }^{9}$ DA MSP, PA, 1947, f. 50, br. 4424. 
Trgovinskog biroa u Milanu ukoliko se ne odobri reciprocitet - otvaranje istog biroa u Jugoslaviji. ${ }^{10} \mathrm{Na}$ osnovu instrukcija pomoćnika ministra inostranih poslova Vladimira Velebita od 27. decembra trebalo je insistirati na tome da je italijanska vlada već preuzela obavezu da dozvoli otvaranje biroa u Milanu i da zahtev za reciprocitetom predstavlja novo uslovljavanje. ${ }^{11}$ Jugoslovenska vlada $\mathrm{u}$ tom trenutku još uvek nije imala formiran stav o pitanju prihvatanja reciprociteta.

Jugoslovenski delegat u Savetodavnom veću dr Sloven Smodlaka obavestio je 31. decembra Velebita da mu je Franćesko Franconi (Francesco Franzoni), zamenik generalnog sekretara Ministarstva inostranih poslova, rekao da će jugoslovenska vlada biti zvanično obaveštena o tome da jugoslovenski Trgovinski biro u Milanu može da radi, ali pod uslovom reciprociteta. ${ }^{12}$ Smodlaka je podsetio Franconija da su uslovi za otvaranje biroa u Milanu bili precizirani tokom pregovora u oktobru i da je jugoslovenska vlada već učinila ustupak time što je pristala na klirinški račun u lirama. Franconi se pravdao time da mu to nije poznato i rekao da ta činjenica potpuno menja situaciju. Pitao je da li bi jugoslovenska vlada ipak dozvolila otvaranje italijanskog trgovinskog biroa u Beogradu, ali Smodlaka je naveo da nije imao ovlašćenja da odgovori.

U depeši koju je 2. januara 1947. uputio Ivanu Antuncu, ekonomskom savetniku Jugoslovenske delegacije u Savetodavnom veću, ministar spoljne trgovine Nikola Petrović je naveo da je jugoslovenska vlada veoma zainteresovana za italijansko tržište, posebno za uvoz i izvoz većih količina drveta i uglja tokom 1947. ${ }^{13}$ Petrović je preporučio Antuncu da proveri ko bi sa italijanske strane bio najpovoljniji partner, ali je preneo da jugoslovenska vlada nema nameru da potpisuje trgovinski ugovor sa Italijom. Sugerisao je da bi za takve poslove bila potrebna neformalna saglasnost italijanskog Ministarstva spoljne trgovine.

U cilju podrobnijeg informisanja jugoslovenske vlade o međunarodnopravnom statusu trenutnih jugoslovensko-italijanskih trgovinskih odnosa, na ove instrukcije ministra Petrovića reagovao je Smodlaka. On je 7. januara podsetio Velebita da već postoji poluslužbeni ugovor o kliringu i zameni dobara, da je na osnovu tog ugovora i otvoren jugoslovenski Trgovinski biro u Milanu, kao i da je u tom trenutku bilo nemoguće stvarati neki novi poluslužbeni odnos. ${ }^{14}$ Naveo je da je sporazum o kliringu toliko elastičan da se njime bez ikakvih traženja specijalnih saglasnosti od italijanskog

\footnotetext{
${ }^{10}$ DA MSP, PA, 1947, f. 50, br. 15195.

${ }^{11}$ DA MSP, PA, 1947, f. 50, br. 15195

12 DA MSP, PA, 1947, f. 50, br. 4424.

${ }^{13}$ DA MSP, PA, 1947, f. 50, br. 41325.

${ }^{14}$ DA MSP, PA, 1947, f. 50, br. 41325.
} 
Ministarstva spoljne trgovine, može obuhvatiti sva roba koju Jugoslavija želi da proda, odnosno kupi od Italije tokom 1947. Zbog toga je Smodlaka insistirao na tome da je najbolje da se jugoslovenska vlada u institucionalizaciji trgovinske razmene zadovolji onim što već postoji, jer bi u suprotnom italijanska vlada kroz pregovore o trgovinskom sporazumu ucenjivala sa zahtevom za uspostavljanje diplomatskih odnosa. Smodlaka je negodovao zbog zanemarivanja Jugoslovenske delegacije u Savetodavnom veću i predložio Velebitu da obavesti ministra Petrovića o neophodnosti većeg angažovanja i informisanja njenog Ekonomskog odeljenja o svim trgovinskim poslovima koje bi neka jugoslovenska ustanova sklopila sa Italijom. Naveo je da Ekonomsko odeljenje delegacije dobro poznaje tržište i zakonske propise u Italiji, kao i da je u stalnom kontaktu sa italijanskim Ministarstvom spoljne trgovine, koje je već tražilo da se Italiji proda drvo i ugalj. Kroz omogućavanje povoljnih trgovinskih aranžmana, Smodlaka je sagledavao mogućnost dobijanja različitih diplomatskih ustupaka od italijanske vlade, pre svega viza. U tom smislu, on je predložio Velebitu da u Italiju putuju samo oni jugoslovenski stručnjaci koji su neophodni i čiji poslovi ne mogu da se obave direktno u Trgovinskom birou u Milanu. Smodlaka je 20. januara obavestio Velebita da je Franconi potpisao rešenje da se prima na znanje otvaranje jugoslovenskog Trgovinskog biroa u Milanu, ali pod uslovom reciprociteta. ${ }^{15}$

Uspostavljanje diplomatskih odnosa i otvaranje konzulata u Milanu bilo je neophodno kako bi Jugoslavija mogla da šalje svoje trgovinske predstavnike. Smodlaka je tokom decembra 1946. i januara 1947. na ovu činjenicu više puta ukazivao Velebitu. ${ }^{16}$

Šef jugoslovenskog Trgovinskog biroa u Milanu bio je najpre dr Ante Krstulović, a zatim dr Oton Rada do aprila 1948, kada je određen za privremenog vršioca dužnosti trgovinskog izaslanika u Rimu. ${ }^{17}$ Trgovinski biro je delovao pod nazivom „Jugokombiro“. Jugoslovenski ministar inostranih poslova Stanoje Simić obavestio je 24. januara Smodlaku da jugoslovenska vlada pristaje da Italija otvori trgovinski biro na jugoslovenskoj teritoriji. ${ }^{18} \mathrm{U}$ skladu sa principom reciprociteta na koji se jugoslovenska vlada obavezala, ubrzo su počele pripreme za otvaranje italijanskog Trgovinskog biroa u Beogradu. O tome je načelnik Konzularno-privrednog odeljenja Ministarstva inostranih poslova Lazarević, 1. februara obavestio Ministarstvo spoljne trgovine. ${ }^{19}$

\footnotetext{
${ }^{15}$ DA MSP, PA, 1947, f. 50, br. 41182.

${ }^{16}$ DA MSP, PA, 1947, f. 50, br. 4446.

${ }^{17}$ DA MSP, PA, 1948, f. 65, br. 417737.

${ }^{18}$ DA MSP, PA, 1947, f. 50, br. 41182.

${ }^{19}$ DA MSP, PA, 1947, f. 55, br. 42180.
} 


\section{Potpisivanje trgovinskog sporazuma između Jugoslavije i Italije}

O nameri da se pokrenu pregovori o trgovinskom sporazumu između dve zemlje, razgovarali su Josip Broz i generalni sekretar Komunističke partije Italije i bivši ministar pravde Palmiro Toljati (Palmiro Togliatti), tokom njegove posete Beogradu od 3. do 5. novembra $1946 .{ }^{20} \mathrm{U}$ kominikeu italijanske vlade 7. novembra ovi razgovori pozitivno su ocenjeni. Na potrebu potpisivanja trgovinskog sporazuma ukazao je 13. novembra i lider Demohrišćanske partije Alćide de Gasperi (Alcide de Gasperi), inače veliki protivnik uspostavljanja direktnih pregovora sa Jugoslavijom. ${ }^{21}$ Potpisivanje trgovinskog ugovora bilo je jedna od tema direktnih jugoslovenskoitalijanskih pregovora koji su planirani tokom decembra 1946, ali koji su ostali nerealizovani. ${ }^{22}$ Iako je, kao što smo već naveli, 2. januara 1947. tvrdio da jugoslovenska vlada nema nameru da potpisuje trgovinski ugovor, ministar Petrović je 17. februara potpisao akt kojim se Ministarstvo spoljne trgovine FNRJ obratilo Kabinetu pomoćnika ministra inostranih poslova sa molbom da se Antuncu šifrovanim telegramom uputi odluka o spremnosti jugoslovenske vlade da sa Italijom otpočne službene pregovore o sklapanju trgovinskog sporazuma. ${ }^{23}$ Ministar Simić je 18. februara obavestio jugoslovensku delegaciju u Savetodavnom veću o svim detaljima u vezi sa pripremom pregovora. ${ }^{24}$ Ministarstvo spoljne trgovine smatralo je da je bolje da formalna inicijativa dođe sa italijanske strane i Antuncu je poslata instrukcija da nadležnim italijanskim krugovima sugeriše da ponude trgovinske pregovore, uz napomenu da će jugoslovenska vlada pregovore odmah prihvatiti. Kao mesto pregovora predložen je Beograd. Antunac je obavešten da je poželjno da pregovori počnu što pre, a po mogućstvu početkom marta. Stavljeno mu je $\mathrm{u}$ zadatak da ispita kakvo je mišljenje italijanske vlade $o$ karakteru samog sporazuma i njegovom obimu. Takođe je trebalo da ispita i da li postoji mogućnost dobijanja nekog kredita ako se jugoslovenska vlada obaveže na isporuku većih količina uglja, drveta i sličnog materijala. $\mathrm{Na}$ kraju telegrama, ministar Simić je poručio Antuncu da kada završi sve pripremne radove $u$ Rimu, treba da dođe $u$ Beograd da sarađuje na pripremi pregovora. Tokom ispitivanja mogućnosti da inicijativa dođe sa italijanske strane, jugoslovenskim predstavnicima je istaknuta potreba da Jugoslavija isporuči Italiji veće količine životnih namirnica. ${ }^{25}$ Jugoslovenski otpravnik

${ }^{20}$ Miljan Milkić, Tršćanska kriza u vojno-političkim odnosima Jugoslavije sa velikim silama 1943-1947 (Beograd: INIS, 2012), 153, 154.

\footnotetext{
${ }^{21}$ Isto, 156.

${ }^{22}$ Isto, 157.

${ }^{23}$ DA MSP, PA, 1947, f. 54, br. 42865

${ }^{24}$ DA MSP, PA, 1947, f. 54, br. 42865.

${ }^{25}$ DA MSP, PA, 1947, f. 54, br. 43840.
} 
poslova dr Rudolf Janhuba obavestio je 28. februara Ministarstvo inostranih poslova da je italijanska vlada pristala na razgovore o sklapanju trgovinskog ugovora. ${ }^{26}$ Naveo je da je sve izvedeno na osnovu instrukcija i da je inicijativa pokrenuta sa italijanske strane. Planirano je da sredinom marta za Beograd otputuje misija na čelu sa dr Rafaele Matiolijem (Raffaele Mattioli), administratorom Banka d'Italia. Sa njim su trebali da putuju Pezenti (Pesenti), bivši komunistički ministar i dr Ćezare Mercagora (Cesare Merzagora), ekspert u „Pireliju“ („Pireli“), dok ostali članovi delegacije u tom trenutku nisu bili poznati.

Radi pripreme trgovinskih pregovora, $\mathrm{u}$ Beograd je najpre došao Mercagora. On je 9. marta tokom razgovora sa pomoćnikom ministra inostranih poslova dr Alešom Beblerom i opunomoćenim ministrom dr Milanom Bartošem predao dve promemorije. ${ }^{27} \mathrm{U}$ prvoj promemoriji istaknuti su italijanski interesi u industrijskom, poljoprivrednom, šumarskom, bankarskom i drugim sektorima. Kao važan segment u cilju uspostavljanja ekonomskih odnosa između dve zemlje na međusobnom poverenju kao i na popuštanju postojeće psihološke situacije, postavljeno je pitanje o tome kakav će biti jugoslovenski stav prema odredbama Ugovora o miru u vezi sa preduzećima koja su konfiskovana na jugoslovenskoj teritoriji, kao i na teritoriji Julijske krajine. Italijansku vladu je interesovalo i kakav će biti jugoslovenski stav o pitanju konfiskacije italijanskih motornih čamaca koji su zaplenjeni duž dalmatinske obale. Poslednje pitanje bilo je vezano za stav jugoslovenske vlade o zadržavanju železničkih kola koja pripadaju italijanskim državnim železnicama od strane jugoslovenskih državnih železnica. U tom kontekstu, u promemoriji je navedeno da $\mathrm{u}$ domenu transporta robe ne sme da postoji sumnja o sudbini vagona koji se upućuju iz jedne zemlje u drugu. Pozitivno rešavanje svih navedenih pitanja predstavljeno je kao preduslov za „prijateljski napor koji će italijanska industrija poduprta svojom vladom rado učiniti u prilog jugoslovenske privrede“. U drugoj promemoriji italijansko Ministarstvo inostranih poslova je podsetilo da je prema odredbama Beogradskog sporazuma od 19. maja 1939, ${ }^{28}$ jugoslovenska država trebalo da putem obligacija isplati odštetu italijanskim državljanima bivšim vlasnicima zemljišta koja su bila dodeljena seljacima na osnovu agrarne reforme iz $1930 .{ }^{29} \mathrm{U}$ promemoriji je tražen stav jugoslovenske vlade o pitanju obligacija koje je trebalo uručiti, kao i pitanju obligacija koje su već bile uručene i dospele $u$ ruke jugoslovenskim vlastima.

\footnotetext{
${ }^{26}$ Isto.

${ }^{27}$ DA MSP, PA, 1947, f. 54, br. 44691.

${ }^{28}$ Uredba o primeni sporazuma usvojena je 25. jula 1939. i objavljena u: Службене новине, бр. 185-LXIV, 16. 8. 1939, 1165.

${ }^{29}$ DA MSP, PA, 1947, f. 54, br. 44691.
} 
Jugoslovensko poslanstvo u Rimu obavestilo je 10. marta 1947. Ministarstvo inostranih poslova da je italijanska vlada održala nekoliko sastanaka $u$ vezi sa sklapanjem trgovinskog sporazuma. ${ }^{30}$ Tokom marta $u$ Rimu su vođeni pregovori o uslovima nastupa „Fiata“ na jugoslovenskom tržištu, tokom kojih je jugoslovenska strana predlagala plaćanje u sirovinama. Iz jugoslovenskog poslanstva u Rimu Ministarstvo inostranih poslova obavešteno je 15. aprila da je osnova jugoslovenskog izvoza u Italiju apsolutno pogrešna. ${ }^{31}$ Naime, jugoslovenski izvoznici su želeli da maksimalno iskoriste italijanske visoke cene, dok su italijanska ministarstva detaljno ispitivala jugoslovenske molbe i odbijala čak i one jugoslovenske proizvode koji su im bili neophodni ukoliko je stvarna cena bila previsoka. Iz poslanstva je sugerisano da treba tražiti uvozne dozvole na osnovu niže deklarisanih cena, a razliku do stvarne cene naplaćivati u gotovom.

U cilju blagovremene pripreme dolaska italijanske privredne delegacije u Jugoslaviju, italijanski ministar inostranih poslova grof Karlo Sforca (Carlo Sforza) uputio je 26. marta pismo ministru inostranih poslova FNRJ u kome je zamolio da ministar Simić lično, kao i Ministarstvo inostranih poslova, pruže svu potrebnu pomoć šefu delegacije Matioliju. ${ }^{32}$ Sforca je naveo da je Matioli poslat u Jugoslaviju zbog toga što italijanska vlada želi da što više razvije privredne odnose između dve zemlje i da Sforca lično pridaje veliku važnost sve normalnijim i sadržajnijim odnosima između dve susedne zemlje. Jugoslovensko-italijanski trgovinski pregovori završeni su 17. aprila parafiranjem „Sporazuma o trgovinskoj i ekonomskoj saradnji“ između dve zemlje. Prilikom parafiranja sporazuma dogovoreno je da će u roku od dva meseca, računajući od 19. aprila, biti zaključen Protokol o liferacijama za jugoslovenski plan industrijalizacije; klirinški sporazum o razmeni robe za aproksimativnu vrednost od 15 milijardi lira sa svake strane za jednu godinu sa trajanjem od pet godina i pravom otkaza tek posle prve godine uz otkazni rok od šest meseci; isporuka životnih namirnica, kao i obaveza da se nastavi sa dotadašnjim režimom razmene sve do stupanja na snagu parafiranih sporazuma. ${ }^{33} \mathrm{Na}$ sastancima potkomisije za liste isporuka italijanska delegacija je predložila da italijanska preduzeća podignu potopljene brodove u jugoslovenskim vodama, s tim da se Italiji isporuči jedan deo izvađenih brodova kao staro gvožđe. ${ }^{34}$ Jugoslovenska delegacija je prihvatila predlog, ali uz uslov da ni u kom slučaju ne može doći u pitanje pravo vlasništva brodova koji pripadaju jugoslovenskoj državi na osnovu

\footnotetext{
${ }^{30}$ DA MSP, PA, 1947, f. 54, br. 44476.

${ }^{31}$ DA MSP, PA, 1947, f. 54, br. 46953.

32 DA MSP, PA, 1947, f. 54, br. 45881.

${ }^{33}$ DA MSP, PA, 1947, f. 54, br. 410578.

${ }^{34}$ DA MSP, PA, 1947, f. 54, br. 46691.
} 
presuda Jugoslovenskog suda za pomorski ratni plen. Italijanska delegacija je prihvatila takav uslov. Jugoslovenska delegacija je smatrala da ovo pitanje podrazumeva razmatranje komplikovanih tehničkih problema i da nije bilo moguće njegovo rešavanje tokom trgovinskih pregovora. Zbog toga je predloženo da ovo pitanje razmotre jugoslovenski trgovinski delegat i jugoslovenski pomorski ataše u Rimu sa italijanskim predstavnicima. U kominikeu koji je, nakon što ga je Josip Broz odobrio, Ministarstvo inostranih poslova dostavilo Tanjugu 18. aprila, navodi se da je "sporazum stvoren na vrlo širokim temeljima da bi osigurao stvarnu i efikasnu uspostavu odnosa između privreda obeju zemalja i predstavlja važan korak u uspostavljanju prijateljskih odnosa između oba naroda, te je značajan doprinos obnovi i miru u Evropi“". ${ }^{35}$

Ubrzo posle parafiranja, italijanski zvaničnici su svojim izjavama najavili da potpisivanje trgovinskog sporazuma još uvek nije izvesno. Italijanska vlada je nastojala da za ovaj sporazum veže i rešavanje drugih pitanja, pre svega potpisivanje konvencije o ribolovu. Prema informacijama koje je Antunac 12. maja dostavio Vojislavu Srzentiću, pomoćniku ministra spoljne trgovine, u italijanskoj Direkciji za trgovinske sporazume smatrali su da je parafirani sporazum značajan u svim bitnim delovima, ali da je ipak potrebno izvršiti izvesne modifikacije i zatražiti izvesna objašnjenja. ${ }^{36}$ Njihove primedbe odnosile su se na potrebu objašnjenja izraza „koordinacija ekonomskih planova" koja isključuje primenu klauzule najpovlašćenije nacije, smatrali su da je formulacija o nastojanju da se održe što stabilnije uvozno-izvozne cene vrlo neodređena, kao i da je s obzirom na strukturu italijanske ekonomije vrlo teško ostvariti da italijanske vlasti preduzmu obavezu isporuka za Jugoslaviju. Generalni direktor Generalne direkcije izvoza Ministarstva spoljne trgovine dr Stane Pavlić razgovarao je, tokom svog boravka u Italiji, o produženju roka za potpisivanje trgovinskog sporazuma 10. juna sa Matiolijem. ${ }^{37}$ Matioli je ponovio da je sporazum prihvaćen u Italiji, ali da zbog promene kabineta, a posebno zbog izbora novog ministra spoljne trgovine, italijanska strana nije u mogućnosti da do predviđenog roka, 19. juna, dostavi odgovor da li pristaje na potpisivanje sporazuma. ${ }^{38}$ Predložio je ministru Sforci da potpiše sporazum i to bi moglo da se izvrši krajem juna ili početkom jula, naveo je Matioli. Pošto je Sforca tražio

${ }^{35}$ DA MSP, PA, 1947, f. 54, br. 45881.

${ }^{36}$ DA MSP, PA, 1947, f. 54, br. 410578.

${ }^{37}$ DA MSP, PA, 1947, f. 54, br. 410766.

${ }^{38}$ Nova italijanska vlada (četvrta De Gasperijeva vlada) formirana je 31. maja 1947. Karlo Sforca je zadržao resor spoljnih poslova, a za ministra spoljne trgovine postavljen je Ćezare Mercagora. http://www.governo. it/Governo/Governi/de_gasperi4.html (pristupljeno 2. 9. 2015) 
odlaganje potpisivanja sporazuma, Antunac je preneo italijanskoj strani da jugoslovenska vlada pristaje na produženje roka do 15 . jula. ${ }^{39}$ Nakon što je taj rok probijen, poslanik Iveković je 24. jula obavestio Ministarstvo inostranih poslova da Matioli tvrdi da će sa italijanske strane u naredna dva dana sve biti spremno za potpisivanje sporazuma, kao i da je Sforca pristao da potpiše trgovinski sporazum pod uslovom da se potpisivanje izvrši u blizini granice, na Bledu ili u Ljubljani. ${ }^{40}$ Datum potpisivanja bio je jedna od tema i tokom razgovora trgovinskog savetnika italijanskog poslanstva Lazara (Lasaro) sa Bartošem 30. jula. ${ }^{41} \mathrm{Na}$ pitanje Lazara koji su uslovi jugoslovenske vlade za sklapanje konvencije o ribolovu, Bartoš je odgovorio da italijanska strana traži zaključenje takve konvencije i da shodno tome treba da ponudi osnovne uslove.

Iako je u svojim kontaktima tokom jula uveravao jugoslovenske zvaničnike u nameru italijanske vlade da trgovinski sporazum bude uskoro potpisan, poslanik Martino je imao instrukcije ministra Sforce prema kojima potpisivanje ovog sporazuma treba usloviti sklapanjem konvencije o ribarenju. ${ }^{42}$ Nameru italijanske vlade da potpisivanje trgovinskog sporazuma uslovljava sklapanjem ove konvencije, potvrdio je poslanik Iveković 31. jula u telegramu koji je poslao Josipu Brozu, Edvardu Kardelju i Simiću. ${ }^{43}$ Prema Ivekovićevim informacijama, drugi odgovorni faktori spoljne trgovine i privrede bili su za to da se sporazum odmah potpiše i da se posle toga predloži sklapanje konvencije o ribarenju. Iveković je bio uveren i u to da italijanska vlada traži razloge za odlaganje „pod pritiskom agenata SAD“. Tokom razgovora 4. avgusta Sforca je uveravao Ivekovića da je njegova lična želja da se sporazum što pre potpiše i da ne želi da neko novo pitanje odloži potpisivanje. ${ }^{44}$ Kada je Iveković spomenuo instrukcije poslate Martinou, Sforca je rekao da je poznato da se u diplomatiji traži više da bi se postiglo bar nešto, ali da on sada predlaže da se pitanje ribarenja ne vezuje direktno za potpisivanje trgovinskog sporazuma. Iveković je 7. avgusta dobio instrukciju da obavesti Sforcu da jugoslovenska vlada odbija da se potpisivanje trgovinskog sporazuma veže za potpisivanje ribarske konvencije, ali da je spremna da vodi posebne razgovore o tome. ${ }^{45}$ Nakon što je 7. avgusta sa Matiolijem usaglasio stavove dveju vlada u vezi sa mestom potpisivanja sporazuma, Iveković je istog dana obavestio svoju vladu da je ministar Sforca spreman da potpiše sporazum na Bledu ili u Trstu, što bi

${ }^{39}$ DA MSP, PA, 1947, f. 54 , br. 412004.
${ }^{40}$ DA MSP, PA, 1947, f. 54, br. 413920.
${ }^{41}$ DA MSP, PA, 1947, f. 50, br. 414283.
${ }^{42}$ DA MSP, PA, 1947, f. 50, br. 413709.
${ }^{43}$ DA MSP, PA, 1947, f. 54 , br. 414522.
${ }^{44}$ DA MSP, PA, 1947, f. 54 , br. 415093.
${ }^{45}$ DA MSP, PA, 1947, f. 54, br. 414864. 
predstavljalo simboličan gest zbližavanja Jugoslavije i Italije. ${ }^{46}$ Jugosloven- $^{-}$ ski poslanik je istog dana nagovestio da italijanska vlada više ne uslovljava potpisivanje trgovinskog sporazuma sa konvencijom o ribarenju, ${ }^{47}$ a zatim je 11. avgusta i potvrdio da je to stav Sforce, koji je tražio da se izvrši razmena pisama o početku pregovora o ribarenju u roku od dva meseca posle potpisivanja trgovinskog sporazuma. ${ }^{48} \mathrm{Na}$ ovakvo Ivekovićevo tumačenje italijanskih stavova reagovao je Vejvoda iz 1. regionalnog odeljenja. On je 13. avgusta uputio telegram poslanstvu u Rim i naveo da je očigledno da Sforca i dalje vezuje pitanje ribarenja za potpisivanje trgovinskog sporazuma i da ništa ne menja na stvari to što on to traži u formi razmene pisama $o$ početku pregovora o ribarenje posle potpisivanja trgovinskog sporazuma. ${ }^{49}$ Naglasio je da će o pitanju ribarske konvencije biti održani posebni razgovori, a da potpisivanje i sprovođenje trgovinskog sporazuma može samo olakšati te pregovore. Iveković je u telegramu od 13. avgusta uveravao svoje ministarstvo da je Sforca odustao od svojih ranijih stavova i da je to potvrđeno tokom razgovora 4. avgusta. ${ }^{50}$ Uprkos ovim uveravanjima, ministar Simić je 20. avgusta ponovio da poslanstvo u Rimu ne sme da dozvoli bilo kakvo vezivanje potpisivanja trgovinskog sporazuma sa pitanjem ribarenja u bilo kom vidu. ${ }^{51}$

Iako su obe strane izražavale svoje dobre namere, potpisivanje trgovinskog sporazuma ušlo je u kritičnu fazu sredinom septembra. Pritisak javnog mnjenja i pisanje italijanske štampe u vezi sa trgovinskim sporazumom svodilo se na neophodnost rešavanja pitanja ribarenja. U cilju smirivanja javnosti, Sforca je preko poslanika Martinoa tražio da jugoslovenska vlada objavi saopštenje u kome bi izjavila svoju spremnost da se pitanje ribarenja uskoro reši. ${ }^{52}$ Predstavnici jugoslovenskog Ministarstva inostranih poslova odbijali su da daju takvu izjavu, smatrajući da je to samo još jedna forma pritiska na Jugoslaviju. Uveravanja italijanskog poslanika da je "stvar na najboljem putu“ izrečena Velebitu 12. septembra, postala su neodrživa već 16. septembra kada je Iveković javio da italijanska vlada predlaže tekst specijalnog protokola $u$ kome najviše insistira na osiguranju plaćanja sa jugoslovenske strane, a čime bi suština parafiranog sporazuma bila promenjena. ${ }^{53}$ Sa jugoslovenske strane, interesovanje za razloge koji su uticali da italijanska vlada ponovo odloži potpisivanje, dodatno je pojačano zbog

\footnotetext{
${ }^{46}$ DA MSP, PA, 1947, f. 54, br. 415041.

${ }^{47}$ Isto.

${ }^{48}$ DA MSP, PA, 1947, f. 54, br. 415784.

${ }^{49}$ DA MSP, PA, 1947, f. 54, br. 415784.

${ }^{50}$ DA MSP, PA, 1947, f. 54, br. 415596.

${ }^{51}$ DA MSP, PA, 1947, f. 54, br. 415041.

${ }^{52}$ DA MSP, PA, 1947, f. 50, br. 418089.

${ }^{53}$ DA MSP, PA, 1947, f. 54, br. 417905.
} 
prisustva jugoslovenske delegacije zasedanju Generalne skupštine OUN. Na osnovu zahteva ministra Simića, Velebit je 21. septembra obavestio jugoslovensku delegaciji u OUN o nepovoljnom razvoju događaja u vezi sa potpisivanjem sporazuma i za takvu situaciju okrivio italijansku stranu. ${ }^{54} \mathrm{Na}$ osnovu razmene informacija između poslanstva u Rimu i jugoslovenskog Ministarstva inostranih poslova tokom narednih dana, kao i na osnovu razgovora sa poslanikom Martinom 25. septembra, može se zaključiti da su se ekonomski stručnjaci u italijanskoj vladi zalagali za što skorije potpisivanje sporazuma, a da su razlozi za odlaganje bili očigledno politički. ${ }^{55}$

Politički razlozi koji su otežavali jugoslovensko-italijanske trgovinske pregovore bili su pre svega vezani sa ekonomske odnose Sjedinjenih Američkih Država i Italije. U tom kontekstu je važno navesti govor američkog državnog sekretara Džordža Maršala (George Marshall) 5. juna 1947. na Univerzitetu Harvard i pokretanje njegovog plana za obnovu evropske privrede. Shvaćenu kao izrazito politički plan, Maršalovu ideju su ubrzo odbacili Sovjetski Savez i istočnoevropske države. U kontekstu ekonomskih odnosa sa Italijom, jugoslovenska vlada je ovaj plan videla kao veliku prepreku. S druge strane, italijanski ministar inostranih poslova Sforca uputio je 16. juna američkom državnom sekretaru podršku idejama koje je izneo u svom govoru na Harvardu. ${ }^{56}$ Održana na inicijativu Velike Britanije i Francuske od 12. jula do 22. septembra 1947, Pariska konferencija o evropskom ekonomskom oporavku (Conference of Europian Economic Recovery) predstavljala je prvu etapu u prihvatanju Maršalovog plana.

$\mathrm{Na}$ konferenciji je sačinjen izveštaj o evropskim ekonomskim mogućnostima i potrebama za naredne četiri godine i predat Sjedinjenim Američkim Državama. ${ }^{57} \mathrm{Na}$ osnovu sporazuma koji je potpisan 1. jula 1947. SAD su Italiji obećale pomoć u hrani. ${ }^{58}$ Znajući pozicije Jugoslavije u vezi sa Maršalovim planom, italijanske diplomate nisu otvoreno iznosile svoje stavove. Odgovarajući na Ivekovićevo pitanje o tome da li će na stav italijanske vlade o pitanju trgovinskog sporazuma uticati Pariska konferencija, Martino je 18. jula rekao da je Sforca za nezavisnost po pitanju trgovine i da je otišao u Pariz kako ne bi dozvolio uplitanje drugih zemalja u trgovinske poslove Italije. ${ }^{59}$ Ukazujući na to da je američka vlada vršila veliki pritisak na italijansku vladu, Iveković je 9. avgusta u telegramu ministru Simiću

${ }^{54}$ DA MSP, PA, 1947, f. 54, br. 418024.

${ }^{55}$ DA MSP, PA, 1947, f. 54, br. 418415. DA MSP, PA, 1947, f. 50, br. 414283.

${ }^{56}$ Foreign Relations of the United States, 1947, Volume III, The British Commonwealth; Europe, (Washington: U. S. Government Printing Office, 1972), 254.

${ }^{57}$ Ibid., 308-450.

58 Ovakav sporazum SAD su potpisale i sa Grčkom, angloameričkom zonom Slobodne Teritorije Trsta, Austrijom, Mađarskom, Poljskom i Kinom. Ibid., 930.

${ }^{59}$ DA MSP, PA, 1947, f. 50, br. 413709. 
izrazio svoje iznenađenje pozitivnom reakcijom američkog ambasadora $\mathrm{u}$ Rimu Džejmsa Dana (James Clement Dunn) nakon što mu je saopštio mogućnost skorog potpisivanja trgovinskog sporazuma. ${ }^{60}$ Stav o negativnom američkom uticaju Iveković je ponovio i u pismu koje je 27. septembra uputio Velebitu i naveo da se jugoslovenska vlada oko trgovinskog sporazuma sa Italijom „nateže već šest meseci““ ${ }^{61}$ Uprkos svojoj rezigniranosti, Iveković je dodao da postoje realne mogućnosti za potpisivanje i objasnio da se za sporazum zalažu italijanski industrijalci i poslovni ljudi. Kao politički momenat, Iveković je naveo da sporazum podržavaju i „demokratski italijanski krugovi“ koji u sklapanju trgovinskog sporazuma prepoznaju „prvi važan korak približavanja dveju zemalja“. Iveković je, čak, izrazio i sumnju $\mathrm{u}$ pogledu iskrenih namera jugoslovenske vlade i upozorio na neophodnost što skorijeg potpisivanja trgovinskog sporazuma, pre nego što „Amerikanci (ugovorom o prijateljstvu, trgovini) potpuno stave ruku na italijansku ekonomiju".

Iveković je dalje u pismu dao svoju političku analizu značaja trgovinskog sporazuma. Smatrao je da sklapanje trgovinskog sporazuma treba posmatrati kao prvi korak ka rešavanju mnogobrojnih aktuelnih pitanja između Jugoslavije i Italije i kao podršku „italijanskim demokratskim krugovima" koji u približavanju dveju zemalja vide jačanje svojih pozicija. Svoju analizu Iveković je vrlo ambiciozno nastavio tvrdnjom da bi sklapanjem sporazuma Italija bila „izvučena iz začaranog kruga Maršalovog plana“, da bi na taj način Jugoslavija mogla da utiče na pregovore o carinskoj uniji između Francuske i Italije, a da bi sve to dovelo do „slabljenja zapadnog bloka“. Konačno, „italijanske demokratske snage“ bile bi u stanju da pruže ozbiljan organizovani otpor „politici zarobljavanja sa strane američkog imperijalizma". Smatrao je da jugoslovenska vlada jedino treba da vodi računa o ekonomskim razlozima, a ne da gubi vreme oko stilizacije teksta sporazuma. Zbog svega navedenog, Iveković je na kraju predložio što hitnije potpisivanje sporazuma ( ubrzati, prihvatiti i što prije potpisati“, istaknuto u originalu - prim. aut.) i još jednom naglasio da mogućnost za potpis još uvek postoji, „uprkos željama De Gasperija, Mercagore i drugih koji su se potpuno vezali za SAD“. Velebit je 2. oktobra obavestio Ivekovića da je Ministarstvo saglasno sa njegovom ocenom o tome da je korisno da Jugoslavija potpiše trgovinski sporazum sa Italijom i tražio hitno objašnjenje $u$ vezi sa tim ko sa italijanske strane postavlja nove uslove. ${ }^{62}$

$\mathrm{Na}$ konferenciji za štampu u Ministarstvu inostranih poslova 2 . oktobra, opunomoćeni ministar Ešref Badnjević preneo je zvaničan stav da

\footnotetext{
${ }^{60}$ DA MSP, PA, 1947, f. 54, br. 415093.

${ }^{61}$ DA MSP, PA, 1947, f. 54, br. 419150.

${ }^{62}$ DA MSP, PA, 1947, f. 54, br. 419099.
} 
jugoslovenska vlada nije odgovorna za odlaganje potpisivanja sporazuma o trgovini i privrednoj saradnji. ${ }^{63}$ Tokom razgovora na večeri u poslanstvu 3. oktobra ministar Mercagora rekao je Ivekoviću da zvanično saopštenje jugoslovenske vlade od prethodnog dana nije tačno i da je italijanska vlada spremna da odmah potpiše ukoliko vlada u Beogradu usvoji novi tekst protokola, a isključio je i mogućnost uticaja sa strane po ovom pitanju. ${ }^{64}$ Atmosfera tokom razgovora nije bila nimalo opuštena, jer je Mercagora pokazivao otvoreno neraspoloženje prema Jugoslaviji i žustro reagovao, dok je Iveković zamerio da kod italijanske vlade ne postoji dobra volja za uspostavljanje dobrih odnosa uprkos zvaničnih izjava. Iveković je 8. oktobra obavestio da mu je istog dana Matioli rekao da će sporazum uskoro biti potpisan i da je italijanska vlada prihvatila njegovu formulaciju. ${ }^{65}$ Narednih desetak dana, međutim, nije bilo napretka u pregovorima, jer, iako je bilo planirano, predstavnici Ministarstva spoljne trgovine nisu otputovali $\mathrm{u}$ Rim. ${ }^{66}$ Nakon što je Iveković 18. oktobra upozorio na ovakvu situaciju, Velebit je 22. oktobra poslao telegram poslanstvu u kome je naveo da jugoslovenski predstavnik uskoro dolazi u Rim da zaključi trgovinski ugovor i da je razlog njegovog kašnjenja bio to što je zaposlen na drugom mestu. ${ }^{67}$

Italijanska vlada je 14. novembra održala sednicu na kojoj je odobrila tekst trgovinskog sporazuma i ovlastila Sforcu da potpiše sporazum. ${ }^{68}$ Sforca se zalagao da se potpisivanje obavi do kraja meseca u Rimu, ali je čekao jugoslovenski pristanak. ${ }^{69}$ Velebit je o tome da je italijanska vlada prihvatila da potpiše tekst sporazuma 18. novembra obavestio jugoslovensku delegaciju u Njujorku. ${ }^{70}$ Upravo je delovanje jugoslovenske delegacije na čelu sa ministrom Simićem na zasedanju Generalne skupštine OUN u Njujorku dodatno zaoštrilo političku atmosferu. Dok su jugoslovenski predstavnici sa italijanskim kolegama u Rimu usaglašavali definitivne formulacije protokola, Bebler je na zasedanju Generalne skupštine govorio o stranom uticaju i optužio italijansku vladu za sabotiranje pregovora. ${ }^{71} \mathrm{Na}$ ovakvu izjavu oštro je reagovao Sforca i odbacio optužbe, dok je jugoslovenski poslanik u Rimu 11. novembra u telegramu svom ministarstvu ocenio da za Beblerovu izjavu nije izabran „srećan momenat“. ${ }^{72}$ Da za ovakvu

\footnotetext{
${ }^{63}$ DA MSP, PA, 1947, f. 54, br. 419156.

${ }^{64}$ DA MSP, PA, 1947, f. 54, br. 419311.

${ }^{65}$ DA MSP, PA, 1947, f. 54, br. 419670.

${ }^{66}$ Isto.

${ }^{67}$ DA MSP, PA, 1947, f. 54, br. 420673.

${ }^{68}$ DA MSP, PA, 1947, f. 54, br. 423023.

${ }^{69}$ DA MSP, PA, 1947, f. 54, br. 422790.

${ }^{70}$ DA MSP, PA, 1947, f. 54, br. 423230.

${ }^{71}$ DA MSP, PA, 1947, f. 54, br. 422731.

${ }^{72}$ Isto.
} 
izjavu nije odabran pravi trenutak, potvrdio je 16. novembra i ministar Simić i ukazao na ozbiljne propuste u dostavljanju blagovremenih informacija. ${ }^{73} \mathrm{U}$ telegramu upućenom iz Njujorka on je podsetio Velebita da je delegacija mesec dana ranije tražila informacije o stanju pregovora. Tada je odgovoreno da još ništa nije potpisano, ali nisu ni navedene naznake o tome da su u toku bilo kakvi pregovori. Kao logična posledica ovakvih propusta usledio je zaključak koji je Bebler izneo pred Generalnu skupštinu, koji je, kako je Simić naveo, predstavljao jugoslovenski argument protiv Maršalovog plana i protiv ekonomske diskriminacije prema Jugoslaviji. Simić je na kraju telegrama naveo nekoliko činjenica, kojima je izgleda želeo da dokaže da Beblerovom izjavom i nije napravljen veliki propust: trgovinski sporazum je parafiran u martu i još uvek nije potpisan; izmena italijanskog stava nastupila je paralelno sa izmenom američkog stava u planovima ekonomskih odnosa između Zapadne i Istočne Evrope; italijanska vlada je počela da odlaže potpisivanje posle Pariske konferencije o pomoći Evropi; da je promena nastala naročito usled nemogućnosti SAD da sve zemlje Zapadne Evrope snabdevaju ugljem. Dodatni politički pritisak i razlog zbog čega je jugoslovenska delegacija u Generalnoj skupštini oštro reagovala u vezi sa trgovinskim sporazumom, bilo je pitanje revizije Ugovora o miru sa Italijom. Jugoslovenska vlada nije želela da prihvati reviziju, o čemu je i na sednici Generalne skupštine Ujedinjenih nacija 23. septembra govorio dr Ljubomir Leontić. ${ }^{74}$

Predsednik italijanske vlade Alćide de Gasperi izjavio je 17. novembra na kongresu svoje Demohrišćanske stranke u Napulju da je vlada prihvatila trgovinski sporazum sa Jugoslavijom iz političkih razloga koji su prevagnuli nad ekonomskim. ${ }^{75}$ Italijanska vlada, rekao je De Gasperi, prihvatila je sporazum sa izvesnim skrupulama da Italija možda ne može preuzeti tako teške obaveze za liferaciju industrijskih proizvoda na više godina. Dodao je da Italija možda rizikuje da ne održi reč jer se ne zna hoće li Jugoslaviji biti u stanju da uzvraća sirovinama potrebnim za izradu mašina koje Italija treba da liferuje za petogodišnji plan. Prema De Gasperiju, sporazum je odobren da bi se Jugoslaviji pokazalo da će Italija učiniti napore u čitavoj ekonomiji kako bi se uklonile teškoće i stvorila atmosfera za rešavanje delikatnih problema koji su iskrsli stvaranjem novih granica. Isti stav potvrdio je i Sforca sredinom decembra u intervjuu demohrišćanskom listu Il Popolo. ${ }^{76}$

${ }^{73}$ DA MSP, PA, 1947, f. 54, br. 423230.

${ }^{74}$ Dokumenti o spoljnoj politici Socijalističke Federativne Republike Jugoslavije, 1947, II, urednik Miloš Spaić, (Beograd: Jugoslovenski pregled, 1986), 213-215.

${ }^{75}$ DA MSP, PA, 1947, f. 54, br. 423400.

${ }^{76}$ DA MSP, PA, 1947, f. 54, br. 422447. 
Posle odluke italijanske vlade da prihvati sporazum, nastavljeni su kontakti u cilju usaglašavanja mesta i datuma potpisivanja, kao i u vezi sa određivanjem potpisnika. Ministar Sforca je 17. novembra jugoslovenskom poslaniku u Rimu preneo svoju želju da lično potpiše trgovinski sporazum u Rimu ili Veneciji. ${ }^{77}$ Takođe je predložio da ukoliko bude izabran Rim, da u ime FNRJ potpisnik bude Iveković, a ukoliko bi bila Venecija smatrao je da bi jugoslovenski opunomoćnik trebalo da dođe iz Beograda. Sforca je dodao da ukoliko bi jugoslovenska vlada insistirala da potpisivanje bude u Beogradu, Martino bi dobio ovlašćenje da potpiše. U tom slučaju Sforca bi uputio „topli telegram“ jugoslovenskom Ministarstvu inostranih poslova, predložio je da takav telegram uputi i jugoslovenska strana. Iveković je izjavio da nema nikakvih novih instrukcija i da za njega važe instrukcije prema kojima bi se potpisivanje obavilo u Beogradu. Sredinom novembra jugoslovensko poslanstvo je dobilo hitan zadatak da organizuje prodaju 20.000 tona kukuruza, šećera, duvana, kao i drvnu građu radi nabavke sredstava za kupovinu tekstilnog prediva. ${ }^{78}$ Iveković je iskoristio razgovor 17. novembra da Sforci predloži navedene hitne jugoslovenske liferacije i rekao da u velikoj meri od njega zavisi da li će jugoslovenska inicijativa naići na razumevanje kod ekonomskih faktora italijanske vlade. Naglasio je želju jugoslovenske vlade za ubrzanjem i poboljšanjem razmene i podvukao politički momenat $u$ vezi sa liferacijom kukuruza. Sforca je obećao da će o ovom pitanju odmah obavestiti Ministarstvo spoljne trgovine i rekao da smatra da neće biti teškoća. Iveković je u izveštaju svom Ministarstvu naglasio da Sforca uopšte nije informisan o situaciji na italijanskom tržištu i da njegov "legendarni optimizam treba uzeti sa rezervom“. ${ }^{79}$ Takođe je ukazao na objektivne teškoće $u$ vezi sa prodajom kukuruza jer SAD žuri da liferuje Italiji žito u vrednosti od 128 miliona dolara do marta 1948.

Velebit je 19. novembra obavestio poslanstvo u Rimu da je jugoslovenska vlada saglasna sa predlogom da trgovinski ugovor potpiše Iveković u Rimu kao i da se uputi telegram na dan potpisivanja ${ }^{80}$ Punomoćje za potpisivanje doneo je u Rim 21. novembra načelnik Odeljenja za trgovinske sporazume Ministarstva spoljne trgovine Zoran Budišin. ${ }^{81}$ Poslanik Iveković je 24. novembra sa Sforcom dogovorio da se potpisivanje trgovinskog sporazuma izvrši 28. novembra u 12 časova. ${ }^{82}$ Potpisivanje "Sporazuma o trgovini i ekonomskoj saradnji“ obavljeno je u dogovoreno vreme na svečanoj ceremoniji u sedištu italijanske vlade („Palaco Kiđi“) u prisustvu funkcio-

\footnotetext{
${ }^{77}$ DA MSP, PA, 1947, f. 54, br. 423268.

${ }^{78}$ DA MSP, PA, 1947, f. 54, br. 423262.

${ }^{79}$ DA MSP, PA, 1947, f. 54, br. 423268.

${ }^{80}$ DA MSP, PA, 1947, f. 54, br. 423268.

${ }^{81}$ DA MSP, PA, 1947, f. 54, br. 423608.

82 DA MSP, PA, 1947, f. 54, br. 424033.
} 
nera italijanskog Ministarstva inostranih poslova. ${ }^{83}$ Posle potpisivanja Sforca je održao kraći govor o značaju sporazuma za dobre odnose između Jugoslavije i Italije, a Iveković je odgovorio „kraćom općenitom izjavom“. Sforca je u svom govoru rekao i to da sporazum potpisuje jer će se time rešiti i za Italiju najvažnije pitanje - pitanje ribarenja. ${ }^{84} \mathrm{Na}$ osnovu postignutog dogovora, prilikom potpisivanja sporazuma izvršena je razmena telegrama. ${ }^{85}$ Sporazum je stupio na snagu danom potpisivanja. Sa jugoslovenske strane, za sprovođenje odredbi sporazuma bila je zadužena Narodna banka. ${ }^{86}$

Tokom razgovora Ivekovića sa direktorom političkog odeljenja Ministarstva inostranih poslova, opunomoćenim ministrom Zopijem (Vittorio Zoppi), 18. decembra konstatovano je da je potpisivanje trgovinskog ugovora Jugoslavije i Italije dokaz da je saradnja moguća. ${ }^{87}$ Ipak, bilo je stavova koji su sa italijanske strane podsećali da je sporazum potpisan iz političkih, a ne ekonomskih razloga. Generalni direktor Ekonomskog odeljenja Ministarstva inostranih poslova Graci (Grazi) je 5. januara 1948. tokom razgovora sa Ivekovićem pokrenuo pitanje ribolova u teritorijalnim vodama Jugoslavije. ${ }^{88}$ Naveo je da je on lično podržavao trgovinski sporazum, verujući da će jugoslovenska vlada ispuniti svoje obećanje i rešiti pitanje ribolova. Sa žaljenjem je konstatovao da će zbog nerešenog pitanja ribolova doći u pitanje izvršenje trgovinskog sporazuma. Od Gracijeve izjave ogradio se Franconi 13. januara, naglasivši Ivekoviću da Graci nije bio ovlašćen da tako nešto izjavi. ${ }^{89} \mathrm{Na}$ večeri u jugoslovenskom poslanstvu 17. februara, Sforca, ministar odbrane Paćardi (Randolfo Pacciardi), Franconi i Martino naglasili su Ivekoviću potrebu dobrih susedskih odnosa i istakli da se trgovinski sporazum mora sprovesti u život. ${ }^{90}$

Potpisivanje sporazuma nije značajnije uticalo na razvoj trgovinskih odnosa tokom narednih meseci. U izveštaju koji je 27. februara 1948. sastavljen u Odeljenju trgovinskih sporazuma Ministarstva spoljne trgovine konstatuje se da se izvršenje ovog sporazuma sprovodi vrlo slabo. ${ }^{91}$ Kao glavni razlog navedena je činjenica da kod Italijana postoji takozvani sistem raspodele kontingenata, odnosno italijansko Ministarstvo spoljne trgovine rešavalo je dva puta godišnje molbe za uvoz, odnosno izvoz, i na osnovu tih

\footnotetext{
${ }^{83}$ DA MSP, PA, 1947, f. 54, br. 424374.

${ }^{84}$ DA MSP, PA, 1948, f. 65, br. 427910.

${ }^{85}$ DA MSP, PA, 1947, f. 54, br. 424143.

${ }^{86}$ DA MSP, PA, 1948, f. 65, br. 483.

${ }^{87}$ DA MSP, PA, 1947, f. 49, br. 426603.

${ }^{88}$ DA MSP, PA, 1948, f. 65, br. 4763.

${ }^{89}$ DA MSP, PA, 1948, f. 65, br. 41463.

${ }^{90}$ DA MSP, PA, 1948, f. 72, br. 44709.

${ }^{91}$ DA MSP, PA, 1948, f. 65, br. 45637.
} 
molbi izdavalo podnosiocima uvozne i izvozne dozvole. Prva raspodela kontingenata treba da se izvrši početkom marta i tada će međusobna razmena biti daleko efikasnija. Do 20. marta 1948. iz Italije u Jugoslaviju uveženo je robe u vrednosti od oko 4 milijarde lira, dok je izvoz u Italiju iznosio oko 1 milijarde i 200 miliona. $^{92}$ Poslanik Iveković je 23. maja 1948. zaključio da Jugoslavija od italijanskih vlasti ne nailazi na veće poteškoće u primeni trgovinskog sporazuma, već da su najveće poteškoće $u$ ispunjavanju jugoslovenskih obaveza. Kao primer, naveo je da je Jugoslavija u tom trenutku mogla da izveze samo drvo. Loše stanje robne razmene dovelo je do toga da su se Iveković i Sforca 3. oktobra 1948. saglasili o tome da je potrebno obnoviti pregovore o trgovinskom sporazumu. ${ }^{93}$ Sforca je, naravno, predložio da se istovremeno pristupiti i pregovorima o ribolovu. Iveković je 6 . novembra 1948. obavestio svoje Ministarstvo da je u razgovoru sa direktorom italijanskog Ministarstva inostranih poslova i njegovim zamenikom, postavio zahtev za početak pregovora o dopunama i izmenama trgovinskog sporazuma. ${ }^{94}$ Oni su načelno prihvatili i izrazili svoje interesovanje za početak pregovora o ribolovu. Sredinom decembra 1948. jugoslovenska vlada je formulisala glavne ciljeve pregovora: 1) trebalo je da se utvrde uvozne i izvozne kontingentne liste za 1949. po redovnom prometu i investicionim isporukama; 2) zahtevaće se da se uprosti tehnika plaćanja u pogledu obostranih otvaranja akreditiva; 3) mogućnost regulisanja recipročnih poslova preko kliringa; 4) pitanje kompenzacija i reeksportnih (triangularnih) poslova; 5) tražiće se povećanje maksimuma na računu „A“ koji je do tada iznosio dve milijarde lira i eventualno finansiranje sa italijanske strane avansa koje jugoslovenski uvoznici plaćaju italijanskim prodavcima po dugoročnim narudžbinama. ${ }^{95}$ Novi sporazum o trgovini između Jugoslavije i Italije potpisan je 4 . avgusta 1949, sa rokom važenja od godinu dana. Razmenom pisama 12. avgusta 1950. između Matesa i Martinoa važnost sporazuma produžena je do 3 . avgusta 1951 . $^{96}$

Pregovori o potpisivanju trgovinskog sporazuma između Jugoslavije i Italije odvijali su se u atmosferi političke krize i loših bilateralnih odnosa. Mnogobrojna nerešena politička pitanja, kao i međunarodne okolnosti, uticala su na tok pregovora. Nerešeno pitanje statusa grada Trsta i čitave Julijske krajine imali su uticaj na stvaranje atmosfere nepoverenja i povećanih

${ }^{92}$ DA MSP, PA, 1948, f. 65, br. 413867.

${ }^{93}$ DA MSP, PA, 1948, f. 65, br. 425641.

${ }^{94}$ DA MSP, PA, 1948, f. 71, br. 428730.

${ }^{95}$ DA MSP, PA, 1948, f. 65, br. 431231.

${ }^{96}$ Arhiv Jugoslavije (AJ), fond Kabinet Maršala Jugoslavije (KMJ), 836, I-3-b/342. 
tenzija. Gotovo bezrezervna politička i ekonomska podrška koju je Italija dobijala od vlade SAD otežavala je pregovaračke pozicije jugoslovenske vlade. Politički odnosi između SAD i SSSR-a pogoršani su Maršalovim planom, koji je pokrenut upravo u trenutku kada je bilo aktuelno potpisivanje jugoslovensko-italijanskog trgovinskog sporazuma. Uslovljavanje potpisivanja trgovinskog sporazuma sa rešavanjem drugih problema između Jugoslavije i Italije, posebno sa pitanjem ribarenja, otežavalo je pregovore i naglašavalo njihov politički karakter. Trgovinska pitanja sagledavana su u kontekstu političkih odnosa i ekonomski razlozi nisu bili presudni. Pažljivo pripreman tokom konsultacija stručnjaka dveju zemalja, trgovinski sporazum je u aprilu 1947. parafiran, ali je na kraju potpisan u novembru iste godine pod političkim pritiskom. Bilo je potrebno da prođe nekoliko meseci da bi dve vlade odbacile političke razloge i pristupile pripremama za potpisivanje novog sporazuma zasnovanog na ekonomskim potrebama i tržišnoj logici.

\section{IZVORI I LITERATURA}

Arhiv Jugoslavije (AJ), fond Kabinet Maršala Jugoslavije (KMJ), 836.

Diplomatski arhiv Ministarstva spoljnih poslova (DA MSP), Politička arhiva (PA), 1947.

„Споразум између Краљевине Југославије и Краљевине Италије о примени аграрне реформе на италијанске држављане у прећашњој покрајини Далмацији“. Службене новине, бр. 185-LXIV, 16. август 1939, 1165.

„Указ о ратификацији Уговора о миру са Италијом“. Службени листи ФНРЈ, 29. август 1947, 1001-1085.

Dokumenti o spoljnoj politici Socijalističke Federativne Republike Jugoslavije, 1947, II. Urednik Miloš Spaić. Beograd: Jugoslovenski pregled, 1986.

Foreign Relations of the United States, 1947, Volume III, The British Commonwealth; Europe. Washington: U. S. Government Printing Office, 1972.

Милкић, Миљан. „уугославија, велике силе и питање статуса

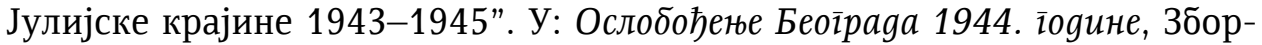
ник радова. Уредник Александар Животић, 282-296. Београд: ИНиС, 2010.

Милкић, Миљан. „Гашење југословенске краљевске војне мисије у Италији 1945“. Војноистиоријски іласник, бр. 2, (2010), 149-166.

Milkić, Miljan. Tršćanska kriza u vojno-političkim odnosima Jugoslavije sa velikim silama 1943-1947. Beograd: INIS, 2012.

http://www.governo. it/Governo/Governi/de_gasperi4.html (pristupljeno 2. 9. 2015) 
Miljan Milkić

\title{
RENEWAL OF YUGOSLAV-ITALIAN TRADE RELATIONS AFTER THE SECOND WORLD WAR
}

\begin{abstract}
Summary
Negotiations on the signing of the post-World War II trade agreement between Yugoslavia and Italy were held in an atmosphere of political crisis and deteriorating bilateral relations. Numerous unresolved mutual political issues as well as tense international circumstances influenced the course of the negotiations. The unresolved issue of the status of the city of Trieste and the entire Venezia Giulia created an atmosphere of mistrust and increased tensions. The substantial political and economic support provided by the United States to Italy caused further difficulties for the negotiating position of the Yugoslav government. Political relations between the United States and the Soviet Union became very difficult after the Marshall Plan, which began to be implemented in June 1947. During this period, the Yugoslav-Italian trade agreement was signed. This trade agreement was contingent on solving other issues between Yugoslavia and Italy, particularly those relating to fishing, and this hampered negotiations and intensified its political character. Trade issues were perceived in the context of political relations and economic reasons were not decisive. The trade agreement, carefully prepared during mutual consultations of experts of both countries, was initialed on 17 April 1947 and signed on 28 November 1947 under political pressure. This apparent treaty signing delay was caused by the two governments downplaying political considerations and recognizing the urgent economic needs of market logic. The new trade agreement between Yugoslavia and Italy was finally signed on 4 August 1949.
\end{abstract}

KEYWORDS: Yugoslavia, Italy, Peace Treaty, Yugoslav Trade Office in Milano, Trade agreement, political relations, Marshall Plan 


\section{RINNOVO DEI RAPPORTI COMMERCIALI TRA LA JUGOSLAVIA E L'ITALIA DOPO LA SECONDA GUERRA MODIALE}

\section{Sommario}

Le trattative per la firma sull'accordo commerciale tra Jugoslavia e Italia si sono svolte in un clima di crisi politica e cattive relazioni bilaterali. Molte questioni politiche irrisolte, nonchè le circostanze internazionali, hanno influenzato sullo svolgimento delle trattative commerciali. La questione irrisolta dello status della città di Trieste e l'intera Venezia Giulia, ha creato un clima di aumento di tensione e diffidenza. Il sostegno politico ed economico, praticamente incondizionato, che l'Italia riceveva dal governo degli Stati Uniti, aveva complicato le posizioni negoziali del governo jugoslavo. I rapporti politici tra gli USA e l'URSS deteriorati per causa del Piano Marshall, il quale è entrato in vigore nel giugno del 1947, nell'istante in cui era in corso la firma sull'accordo commerciale jugoslavoitaliano. La firma dell'accordo commerciale eracondizionata dalla risoluzione degli altri problemi tra Jugoslavia e Italia, in primis la questione della pesca che ostacolava le trattative sottolineando il loro carattere politico. Nelle trattative commerciali era preminente il contesto politico, mentre meno importante erano i motivi economici. Preparato accuratamente con la reciproca consultazione di esperti dei due paesi, l'accordo commerciale è stato siglato in 17 aprile 1947, ma viene confermato, sotto pressione politica il 28 novembre 1947. E' stato necessario che passassero alcuni mesi durante i quali i due governi hanno respinto le ragioni politiche e si unirono per comporre le trattative per un nuovo accordo commerciale basato sulle esigenze economiche e logica di mercato. Il nuovo accordo commerciale tra Jugoslavia e Italia viene firmato il 4 agosto 1949.

PAROLE CHIAVE: Jugoslavia, Italia, Trattato di pace, Ufficio commerciale jugoslavo a Milano, accordo commerciale, relazioni politiche, Piano Marshal 